\title{
Temperature response to severe head injury and the effect on body energy expenditure and cerebral oxygen consumption
}

\author{
D S F Matthews, R E Bullock, J N S Matthews, A Aynsley-Green, J A Eyre
}

\begin{abstract}
This study examines the relationship between core temperature and whole body energy expenditure, cerebral oxygen consumption $\left(\mathrm{CMRO}_{2}\right)$, cerebral blood flow (CBF), and intracranial pressure (ICP) in severely head injured children. A total of 107 serial measurements of temperature, energy expenditure, $\mathrm{CMRO}_{2}, \mathrm{CBF}$, and ICP were made in 18 head injured children receiving neurointensive care. Energy expenditure was measured using indirect calorimetry, and $\mathrm{CMRO}_{2}$ and CBF using the Kety-Schmidt technique.

The mean rectal temperature was $37 \cdot 8^{\circ} \mathrm{C}\left(34-39 \cdot 1^{\circ} \mathrm{C}\right)$ despite modification with paracetamol. Within each child there was a positive relationship between rectal temperature and energy expenditure, energy expenditure increasing by a mean of $7.4 \%$ per ${ }^{\circ} \mathrm{C}$. There was no evidence of significant relationships between rectal temperature and $\mathrm{CMRO}_{2}, \mathrm{CBF}$, or ICP. Mild induced hypothermia in two children did not result in decreased $\mathrm{CMRO}_{2}$ or CBF measurements.

The efficacy of interventions aiming to modify cerebral energy metabolism by changing core temperature cannot be readily assessed by the response of the whole body.

(Arch Dis Child 1995; 72: 507-515)
\end{abstract}

Keywords: head injury, temperature.

Disturbance of thermoregulation is frequently described in experimental animals and adult humans after severe trauma ${ }^{12}$ but there are few studies in injured children. ${ }^{34}$ Pyrexia may be viewed with concern as raised body temperature is associated with increased whole body metabolic rate ${ }^{5}$ and an increased incidence of convulsions in children under 5 years of age. Conversely, depressed body temperature may be associated with decreased whole body energy expenditure and, in the non-traumatised brain, decreased cerebral oxygen consumption $\left(\mathrm{CMRO}_{2}\right){ }^{67}$ On the basis of these observations, some centres now include induced hypothermia in their routine management of children with severe head injury in order to decrease intracranial pressure (ICP) and $\mathrm{CMRO}_{2} \cdot{ }^{8}$ Although this study examines the temperature response to severe head injury in children, raised core temperatures were managed aggressively and so the natural temperature response was modified by treatment.
Serial measurements of body temperature were made and related to simultaneous measurements of energy expenditure, $\mathrm{CMRO}_{2}$, cerebral blood flow (CBF), and ICP.

\section{Subjects and methods}

SUBJECTS

The study was part of a larger project examining the hormonal and metabolic response to head injury. ${ }^{9}$ The study was performed in 18 children who had sustained a severe head injury and were receiving neurointensive care. The mean age was $8 \cdot 2$ years with a range of 2 to 15 years. Sixteen children had isolated head injuries and two children had other associated injuries. Associated injuries were defined as injuries severe enough to warrant hospital admission in their own right which is approximately equivalent to an injury severity score of $\geqslant 9 .{ }^{10}$ In all cases the head injury was the most serious injury sustained. The criterion for admission to the study was a Glasgow coma score equal to or less than $8 .^{11}$ In children aged less than 4 years, the adaptation of the Glasgow coma score by James and Trauner was used ${ }^{12}$; the mean score was 6 , range $3-8$. The injury severity score ranged from 10-35, with a mean of 21 . None of the children studied had clinical or laboratory indications of infection. Further clinical details of the children are given in table 1. Ethical approval for the study was granted by the joint ethics committee of Newcastle Health Authority and University of Newcastle upon Tyne and informed written consent was obtained. from the parents.

\section{MANAGEMENT}

The clinical care of the children was the responsibility of the neurointensive care team. All children were intubated and received elective intermittent positive pressure ventilation with mild hyperventilation, arterial partial pressure of carbon dioxide being maintained between $3.5-4.5 \mathrm{kPa}$, with a fractional inspired oxygen concentration of $0.3-0.35$

The children were sedated with continuous intravenous infusions of fentanyl (mean 3.3, range $0.6-8.4 \mu \mathrm{g} / \mathrm{kg} /$ hour); 15 children received a simultaneous infusion of midazolam (mean 110 , range $33-310 \mu \mathrm{g} / \mathrm{kg} /$ hour). All children received muscle relaxants either pancuronium or vecuronium. Seven children were given dopamine (mean 0.46 , range $0.06-0.80$ $\mathrm{mg} / \mathrm{kg} / \mathrm{hour}$ ).

Colloidal solutions were administered as 
Table 1 Clinical details of the 18 head injured children

\begin{tabular}{|c|c|c|c|c|c|c|}
\hline $\begin{array}{l}\text { Age } \\
\text { (years) }\end{array}$ & Sex & $\begin{array}{l}\text { Glasgow } \\
\text { coma } \\
\text { score on } \\
\text { admission }\end{array}$ & Drugs & $\begin{array}{l}\text { Length } \\
\text { of study } \\
\text { (hours) }\end{array}$ & $\begin{array}{l}\text { No of } \\
\text { measurements }\end{array}$ & $\begin{array}{l}\text { Time of first } \\
\text { measurement } \\
\text { (hours after } \\
\text { injury) }\end{array}$ \\
\hline $3 \cdot 4$ & F & $3^{\star}$ & $\begin{array}{ll}\mathrm{F} & 1 \cdot 7-6 \cdot 7 \\
\mathrm{M} & 200-270\end{array}$ & 79 & 8 & 9 \\
\hline $8 \cdot 8$ & $\mathbf{M}$ & 3 & $\begin{array}{ll}\mathrm{F} & 2 \cdot 3 \\
\mathrm{M} & 45-180\end{array}$ & 103 & 9 & 10 \\
\hline $15 \cdot 6$ & F & 3 & $\begin{array}{ll}\mathrm{F} & 0 \cdot 9 \\
\mathrm{M} & 40-75\end{array}$ & 25 & 3 & 20 \\
\hline $\begin{array}{r}4 \cdot 0 \\
10 \cdot 2\end{array}$ & $\begin{array}{l}\mathrm{M} \\
\mathrm{F}\end{array}$ & $\begin{array}{l}4 \\
4 \dagger\end{array}$ & $\begin{array}{ll}F & 1 \cdot 2 \\
F & 2 \cdot 6-4 \cdot 3 \\
M & 35-100\end{array}$ & $\begin{array}{r}9 \\
107\end{array}$ & $\begin{array}{r}2 \\
10\end{array}$ & $\begin{array}{r}7 \\
15\end{array}$ \\
\hline $\begin{array}{r}14 \cdot 0 \\
6 \cdot 4\end{array}$ & $\begin{array}{l}\mathbf{M} \\
\mathbf{M}\end{array}$ & $\begin{array}{l}4 \dagger \\
6\end{array}$ & $\begin{array}{ll}\mathrm{F} & 2 \cdot 5-3 \cdot 8 \\
\mathrm{~F} & 1 \cdot 1-6 \cdot 6 \\
\mathrm{M} & 130-310\end{array}$ & $\begin{array}{r}178 \\
79\end{array}$ & $\begin{array}{r}11 \\
8\end{array}$ & $\begin{array}{r}10 \\
9\end{array}$ \\
\hline $6 \cdot 4$ & F & $6^{\star}$ & $\begin{array}{ll}\mathrm{F} & 2 \cdot 0-4 \cdot 0 \\
\mathrm{M} & 80\end{array}$ & 55 & 6 & 11 \\
\hline 11.5 & $\mathbf{M}$ & 6 & $\begin{array}{ll}\mathrm{F} & \mathbf{4} \cdot 4-5 \cdot 8 \\
\mathrm{M} & \mathbf{8 5 - 1 1 5}\end{array}$ & 83 & 7 & 12 \\
\hline $12 \cdot 0$ & $\mathbf{M}$ & 6 & $\begin{array}{ll}\mathrm{F} & 0.6-1 \cdot 9 \\
\mathrm{M} & 50-75\end{array}$ & 103 & 9 & 9 \\
\hline $8 \cdot 6$ & $\mathbf{M}$ & 7 & $\begin{array}{ll}\mathrm{F} & 3 \cdot 3-5 \cdot 0 \\
\mathrm{M} & 33-100\end{array}$ & 41 & 5 & 10 \\
\hline $9 \cdot 0$ & $\mathbf{M}$ & 7 & $\begin{array}{ll}\mathrm{F} & 4 \cdot 9 \\
\mathrm{M} & 165-230\end{array}$ & 5 & 2 & 14 \\
\hline $11 \cdot 4$ & $\mathbf{M}$ & 7 & $\begin{array}{ll}\mathrm{F} & 1 \cdot 6 \\
\mathrm{M} & 65-95\end{array}$ & 85 & 8 & 11 \\
\hline $2 \cdot 4$ & F & 8 & $\begin{array}{ll}\mathrm{F} & 6 \cdot 4 \\
\mathrm{M} & 170\end{array}$ & 18 & 3 & 36 \\
\hline 2.5 & $\mathbf{M}$ & 8 & $\begin{array}{ll}\text { F } & 2 \cdot 1-8 \cdot 4 \\
M & 85-105\end{array}$ & 61 & 5 & 14 \\
\hline $\begin{array}{l}3 \cdot 5 \\
8 \cdot 6\end{array}$ & $\begin{array}{l}\mathbf{M} \\
\mathbf{M}\end{array}$ & $\begin{array}{l}8 \\
8\end{array}$ & $\begin{array}{ll}\text { F } & 2 \cdot 2 \\
F & 2 \cdot 0 \\
M & 40\end{array}$ & $\begin{array}{l}49 \\
25\end{array}$ & $\begin{array}{l}3 \\
4\end{array}$ & $\begin{array}{l}25 \\
26\end{array}$ \\
\hline $9 \cdot 9$ & $\mathbf{M}$ & 8 & $\begin{array}{ll}\mathrm{F} & 2 \cdot 5-5 \cdot 0 \\
\mathrm{M} & 50-100\end{array}$ & 28 & 4 & 12 \\
\hline
\end{tabular}

$\mathrm{F}=$ fentanyl $(\mu \mathrm{g} / \mathrm{kg} / \mathrm{hour})$ and $\mathrm{M}=$ midazolam $(\mu \mathrm{g} / \mathrm{kg} / \mathrm{hour})$

*Associated injuries. †Induced hypothermia for part of study.

necessary to support normal blood pressure and ensure adequate peripheral perfusion. Intravenous crystalloid fluids were administered at maintenance requirements or with mild fluid restriction ( $75 \%$ of requirements). Nasogastric feeds of nutritionally complete formula were started 24-48 hours after the injury, increasing gradually as tolerated over 2-3 days.

ICP was measured continuously in all children using a subarachnoid catheter with a Camino transducer. ${ }^{13}$ All children had a urinary drainage catheter and peripheral arterial catheter inserted.

Rectal temperature was monitored using a rectal probe and electrical thermometer based on copper/constantan thermocouple sensors accurate to $\pm 0 \cdot 1^{\circ} \mathrm{C}$ (Mon-a-Therm Model 6510, Mallinckrodt). The probe was inserted $5-6 \mathrm{~cm}$ into the rectum. Children were nursed naked covered with a light sheet. The ambient temperature was monitored using a similar thermometer with a probe located close to the child's head. Ambient temperature ranged between 21 and 26 , with a mean of $24^{\circ} \mathrm{C}$

Pyrexial children (rectal temperature $\geqslant 38.5^{\circ} \mathrm{C}$ ) were treated with paracetamol (mean 15, range 9-23 $\mathrm{mg} / \mathrm{kg}$ ) as required. Two children were rendered mildly hypothermic (mean $34 \cdot 0$, range $32 \cdot 6-34.9^{\circ} \mathrm{C}$ ) as part of their management. This was achieved using surface cooling using a water cooling mattress (Hawksley). Continuous infusions of muscle relaxants, either pancuronium or vecuronium, were given. Muscle relaxation was confirmed by transcutaneous nerve stimulation (Microstim, Viamed) to ensure the absence of shivering.

\section{METHODS}

Serial measurements of whole body metabolic rate and cerebral metabolic rate were made in each child as soon as possible after admission to the intensive care unit and repeated every 6-24 hours until the child was no longer receiving neurointensive care. At the time of each measurement the rectal and ambient temperatures were recorded, as was the instantaneous ICP displayed on the Simonsen and Weel pressure module (Simonsen and Weel). An arterial blood sample was taken for the measurement of plasma concentration of adrenaline in all children at the end of the measurement of whole body metabolic rate. However, the hormone data will only be discussed for one of the hypothermic children, the other results having been discussed in a previous paper. ${ }^{9}$ All measurements were made during periods of clinical stability, indicated by stable blood pressure, pulse rate, and temperature.

\section{MEASUREMENT OF WHOLE BODY ENERGY} EXPENDITURE

Whole body metabolic rate was measured by indirect calorimetry using a modified Douglas bag technique. ${ }^{14}$ This method has been described in detail in a previous paper and will only be outlined briefly. ${ }^{9}$ All children were ventilated with a Servo $900 \mathrm{C}$ ventilator using warmed humidified gases. A sample of the inspiratory and all the expiratory gases were collected into $5 \mathrm{~L}$ and $100 \mathrm{~L}$ metallised gas bags (Signal Instrument Company), respectively, over an accurately timed period of 10-20 minutes depending on the minute volume of the child. The bags were then sealed until analysis. One litre of each of the expiratory and inspiratory gases was taken for analysis of oxygen and carbon dioxide concentrations.

Inspiratory and expiratory oxygen concentrations were measured using a paramagnetic oxygen analyser (Servomex 540A, Servomex), modified to analyse discrete $100 \mathrm{ml}$ gas samples and to give a digital readout. Expiratory carbon dioxide concentrations were measured using an infrared carbon dioxide analyser (Servomex PA404, Servomex). Each $100 \mathrm{ml}$ gas sample was dried before analysis by passing it through anhydrous calcium chloride $(\mathrm{BDH})$. Gas samples were analysed in triplicate to ascertain stable results.

The volume of the remaining expired gas was measured using a dry gas meter, DTM200-4 (American Meter Company, distributed by International Gas Apparatus Ltd) and expressed in terms of standard temperature and pressure, dry (STPD) conditions.

Twenty four hour urine collections were made and the total volume of urine measured. Aliquots of $5 \mathrm{ml}$ were stored at $-40^{\circ} \mathrm{C}$ for later determination of total nitrogen content by the Kjeldahl method ${ }^{15}$ using an automated Kjeltac 1026 distillator (Perstorp Analytical Ltd).

The complete indirect calorimetry system was evaluated using nitrogen and carbon 


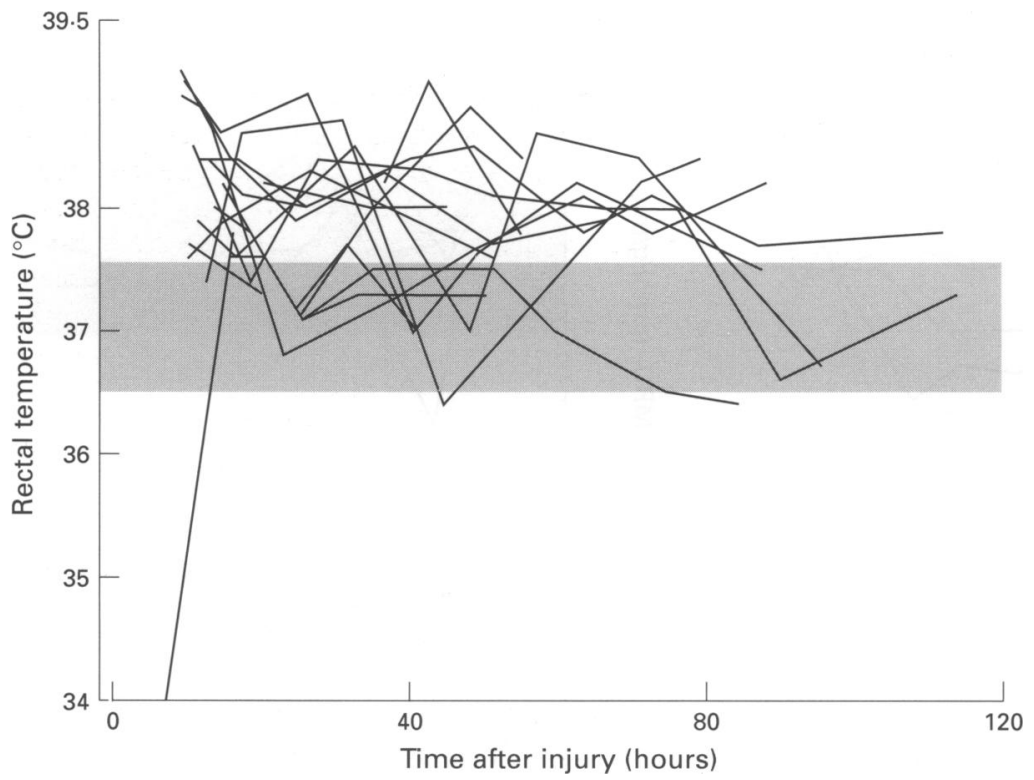

Figure 1 Shows time after injury versus rectal temperature. Each line represents the serial measurements obtained from each child. The shaded area represents the reference range for body temperature for normal resting children.
MEASUREMENT OF $\mathrm{CMRO}_{2}$

Global cerebral blood flow was measured by the Kety-Schmidt technique using $10 \%$ nitrous oxide as the inert tracer. ${ }^{19}$ The Seldinger technique was used to cannulate the internal jugular vein and a catheter (18 or 20 gauge Ledercath, Vygon) was advanced retrogradely until the tip lay in the superior jugular venous bulb. The position of the catheter tip at the base of the skull was confirmed by a lateral radiography of the head and neck. The KetySchmidt technique, which is based on the Fick principle, has been described in detail in a previous paper. ${ }^{20}$

At the end of each measurement of CBF, arterial and superior jugular venous bulb samples $(0.5 \mathrm{ml})$ were obtained. Blood gas analysis was performed using a Radiometer analyser (Corning 1312) and the oxygen saturation $\left(\mathrm{SaO}_{2}\right)$ and haemoglobin $(\mathrm{Hb})$ concentration were measured using a co-oximeter (OSM2 Hemoximeter, Radiometer). Blood oxygen $\left(\mathrm{O}_{2}\right)$ content was calculated according to the equation ${ }^{21}$ :

$$
\mathrm{O}_{2} \text { content }=\mathrm{Hb} \times \mathrm{SaO}_{2} \times 1.39+\left(0.023 \times \mathrm{pO}_{2}\right)
$$

dioxide dilution techniques as described by Westenskow et al. ${ }^{16}$ At a fractional inspired oxygen concentration $\left(\mathrm{FIO}_{2}\right)$ of $0 \cdot 3$, the mean (SD) oxygen consumption $\left(\mathrm{V}_{2}\right)$ recovery was $99.9(2 \cdot 0) \%$ and the mean carbon dioxide production $\left(\dot{\mathrm{V}} \mathrm{CO}_{2}\right)$ recovery was $99 \cdot 4$ $(2 \cdot 0) \%$.

\section{CALCULATIONS}

Whole body metabolic rate was calculated using the equations:

$$
\begin{aligned}
& \dot{\mathrm{V}} \mathrm{O}_{2}=\mathrm{VE}\left[\frac{\left(1-\mathrm{FEO}_{2}-\mathrm{FECO}_{2}\right)}{1-\mathrm{FIO}_{2}}\right] \times \mathrm{FIO}_{2}-\mathrm{FEO}_{2} \\
& \text { (using Haldane transformation) } \\
& \dot{\mathrm{V}} \mathrm{CO}_{2}=\mathrm{VE} \times \mathrm{FECO}_{2} \\
& \text { Energy expenditure }=16.501 \mathrm{Vo}_{2}+4 \cdot 631 \dot{\mathrm{V}} \mathrm{CO}_{2}-9.09 \mathrm{~N} \\
& \left(W^{2 i r}{ }^{17}\right. \text { ) }
\end{aligned}
$$

$\dot{\mathrm{V}} \mathrm{O}_{2}$ and $\dot{\mathrm{V}} \mathrm{CO}_{2}$ in $\mathrm{l} / \mathrm{min}$; $\mathrm{VE}$ is expired volume in $1 / \mathrm{min}$ at STPD; $\mathrm{FIO}_{2}$ is proportion of oxygen in inspiratory gas; $\mathrm{FEO}_{2}$ is proportion of oxygen in mixed expiratory gas; $\mathrm{FECO}_{2}$ is proportion of carbon dioxide in mixed expiratory gas; $\mathrm{N}$ is nitrogen excretion in $\mathrm{g} / \mathrm{min}$; and energy expenditure is $\mathrm{kJ} / \mathrm{min}$. Whole body energy expenditure was expressed in terms of body weight. Body weight was determined in each child by sitting balance scales (Weylux Model 824/890) after discontinuing neurointensive care.

MEASUREMENT OF PLASMA HORMONE CONCENTRATIONS

A $2 \mathrm{ml}$ blood sample was taken from the indwelling peripheral arterial catheter at the end of each gas collection into a heparinised tube. Sample tubes were stored on ice during collection and plasma for adrenaline assay was immediately separated and stored at $-80^{\circ} \mathrm{C}$. Plasma adrenaline was determined by a double isotope radioenzymatic method. ${ }^{18}$ where $\mathrm{Hb}=$ haemoglobin concentration in $\mathrm{g} / 100 \mathrm{ml}$ of blood; $\mathrm{SaO}_{2}=\mathrm{SaO}_{2}$ expressed as a proportion; and $\mathrm{pO}_{2}=$ partial pressure of $\mathrm{O}_{2}$ in $\mathrm{kPa}$. This gives $\mathrm{O}_{2}$ content in $\mathrm{ml} / 100 \mathrm{ml}$ of blood. It was then expressed in $\mu \mathrm{mol} / \mathrm{ml}$ by multiplying by $0 \cdot 446$. The cerebral oxygen consumption was calculated from the equation:

$$
\mathrm{CMRO}_{2}=\mathrm{CBF} \times(\mathrm{A}-\mathrm{V})
$$

Where $\mathrm{CMRO}_{2}$ is in $\mu \mathrm{mol} / \mathrm{g} / \mathrm{min}$; $\mathrm{CBF}$ is in $\mathrm{ml} / \mathrm{g} / \mathrm{min}$; and $\mathrm{A}$ and $\mathrm{V}=$ arterial and cerebrovenous contents of oxygen respectively in $\mu \mathrm{mol} / \mathrm{ml}$.

\section{THE NEED FOR CORRECTION OF CBF AND} $\mathrm{CMRO}_{2}$ FOR TEMPERATURE

The need for correcting CBF for the effects of temperature was considered. Temperature may affect the calculation of CBF by altering the partition coefficient of nitrous oxide $\left(\mathrm{N}_{2} \mathrm{O}\right)$ between blood and brain. The mean temperature coefficient in $\% /{ }^{\circ} \mathrm{C}$ of the Ostwald solubility coefficient of $\mathrm{N}_{2} \mathrm{O}$ is -2.33 in aqueous solutions and about -1.13 in fat. ${ }^{22}$ Brain is only partially composed of fat $(30-40 \%)^{23}$ and so, over a range of $5^{\circ} \mathrm{C}$, the partition coefficient would change by considerably less than $5 \%$. This is within the error of the method for measuring cerebral blood flow and may be ignored.

The need for correcting $\mathrm{CMRO}_{2}$ for the effects of temperature was studied. $\mathrm{CMRO}_{2}$ is expressed in $\mu \mathrm{mol} / \mathrm{g} / \mathrm{min}$ and this expression is independent of temperature. However, temperature may have important effects on the different components measured in blood oxygen content. Haemoglobin concentration and saturation are independent of temperature but the solubility of oxygen varies inversely with temperature, with a change in solubility coefficient of about $-1.5 \% /{ }^{\circ} \mathrm{C} .{ }^{24}$ Over a temperature range of $5^{\circ} \mathrm{C}$, the change in solubility 

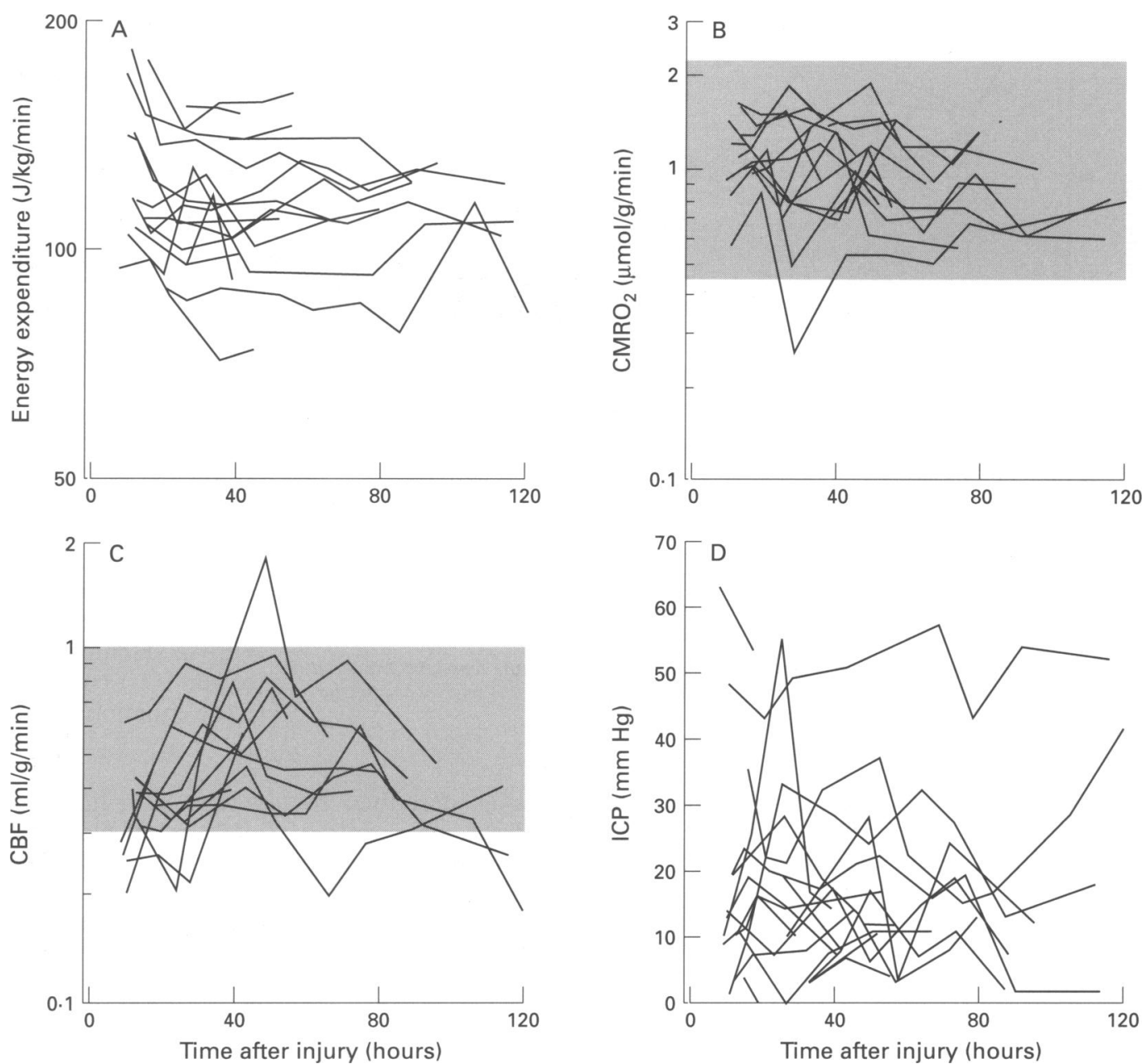

Figure 2 Shows time after injury versus $(A)$ whole body energy expenditure, $(B) C M R O,(C) C B F$, and $(D) I C P$ The shaded area represents the reference ranges for normal children. Whole body energy expenditure, $C M R \mathrm{O}_{2}$ and $C B F$ are plotted on log scales.

coefficient would be $-7 \cdot 5 \%$ resulting in a change in total blood oxygen content of $<1 \%$. However, as $\mathrm{CMRO}_{2}$ is derived from the difference between arterial and cerebrovenous oxygen contents, these changes will affect arterial and venous blood similarly and, thus, any small error will be minimal. In conclusion, $\mathrm{CBF}$ and $\mathrm{CMRO}_{2}$ were not corrected for the effects of temperature.

\section{STATISTICAL ANALYSIS}

In the literature, the effect of temperature on whole body energy expenditure, cerebral metabolic rate, and $\mathrm{CBF}$ is most frequently described in terms of $\%$ change $/{ }^{\circ} \mathrm{C}$, indicating a logarithmic relationship of these variables with temperature. This is in accordance with the van't Hoff law which states that for a rise of $10^{\circ} \mathrm{C}$ the velocity of chemical reactions increases by a factor of 2 or 3 , the $Q_{10}$ effect. In view of these theoretical considerations, whole body energy expenditure, $\mathrm{CMRO}_{2}$ and $\mathrm{CBF}$ underwent logarithmic transformation before analysis. The data were normally distributed after transformation.

The data set is a mixture of cross sectional and longitudinal data. In order to examine the within-child relationships between different variables the data were analysed using multilevel models ${ }^{25}$ fitted using the ML3 program. ${ }^{26}$ This methodology is related to multiple regression and produces similar regression coefficients and standard errors, but allows each child to contribute different numbers of observations. Results are available for within-child analyses, due to centring of explanatory variables. ${ }^{27}$

For graphical presentation, the within-child relationships between temperature and different variables were displayed by calculating the mean for each variable for each child and expressing every observation in terms of the residual from the child's mean. By taking the residuals, the between-child variation was removed and the longitudinal component of the data could be displayed.

\section{Results}

One hundred and seven serial measurements of temperature, energy expenditure and ICP were performed in 18 children. Ninety four serial measurements of $\mathrm{CBF}$ and $\mathrm{CMRO}_{2}$ were performed in 15 of these children. In three children, $\mathrm{CBF}$ and $\mathrm{CMRO}_{2}$ measurements were not obtained because of lack of parental consent, possible cervical spine injury, and failure to site the internal jugular venous bulb line. The median number of 

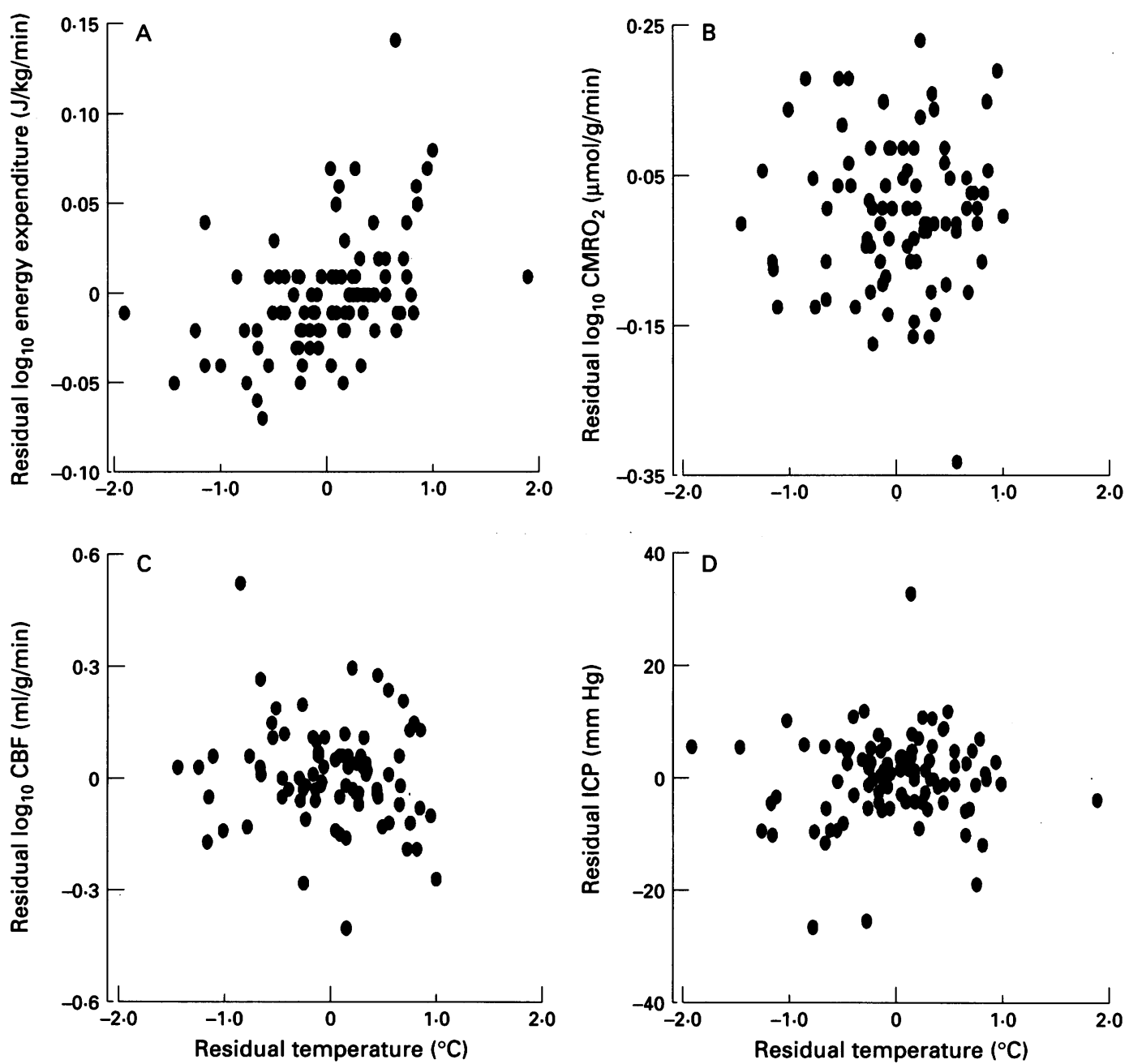

Figure 3 Shows the within child relationships between rectal temperature and $(A) \log _{10}$ energy expenditure, $(B) \log _{10}$ $\mathrm{CMRO}_{2},(C) \log _{10} C B F$, and (D) ICP. Each graph shows the residuals from the mean for rectal temperature and for each of the four variables.

measurements per child was 6 , range $2-11$. The median duration of each study was 58 hours, range 5-178 hours. The median time between injury and the first measurement in all 18 children was $11 \cdot 7$ hours (range 7-36 hours). Nine measurements from the two children with induced hypothermia during active cooling were excluded from the main analysis and will be discussed separately. Fourteen children received paracetamol in 58 out of the 98 remaining measurements. Further details of the results are given in table 1.

\section{RECTAL TEMPERATURE AFTER SEVERE HEAD} INJURY

Figure 1 shows rectal temperature in ${ }^{\circ} \mathrm{C}$ (excluding the measurements from the cooled children) over the first 120 hours after the head injury. This is not the natural pattern of temperature over time as it was considered unacceptable not to intervene with antipyretics for core temperatures $>38.5^{\circ} \mathrm{C}$. The mean rectal temperature was $37.8^{\circ} \mathrm{C}$, range $34-39 \cdot 1^{\circ} \mathrm{C}$. Temperature was within the reference range $\left(36.5-37.5^{\circ} \mathrm{C}\right)$ for $25(26 \%)$ measurements, raised for $69(70 \%)$ measurements from 17 children, and spontaneously below the reference range for four (4\%) measurements from four children.
There was no evidence of a significant correlation between rectal temperature on admission and Glasgow coma score $(p=0 \cdot 88$, $r=0.039$ ).

WHOLE BODY ENERGY EXPENDITURE, $\mathrm{CMRO}_{2}$, CBF, AND ICP AFTER SEVERE HEAD INJURY

Figure 2 shows whole body energy expenditure, $\mathrm{CMRO}_{2}, \mathrm{CBF}$, and ICP together with reference ranges for $\mathrm{CMRO}_{2}$ and $\mathrm{CBF}$ for normal resting children, ${ }^{28}$ over the first 120 hours after the head injury. Energy expenditure was within the reference range for normal resting children as predicted on the basis of age, sex, and weight for $86(82 \%)$ measurements, raised for four (4\%) measurements, and depressed for $15(14 \%)$ measurements. ${ }^{29}$ $\mathrm{CMRO}_{2}$ was within the reference range for 93 (99\%) measurements. CBF was within the

Table 2 Details of analysis by multilevel modelling

\begin{tabular}{lclc}
\hline & \multicolumn{3}{c}{ Rectal temperature } \\
\cline { 2 - 4 } Variable & $\begin{array}{c}\text { Regression } \\
\text { coefficient }\end{array}$ & $S E$ & $p$ Value \\
\hline $\log _{10}$ energy expenditure & 0.031 & 0.0066 & $<0.001$ \\
$\operatorname{ICP}$ & 0.68 & 1.46 & 0.64 \\
$\log _{10}$ CBF & -0.032 & 0.029 & 0.27 \\
$\log _{10}$ CMRO & 0.004 & 0.021 & 0.84 \\
\hline
\end{tabular}



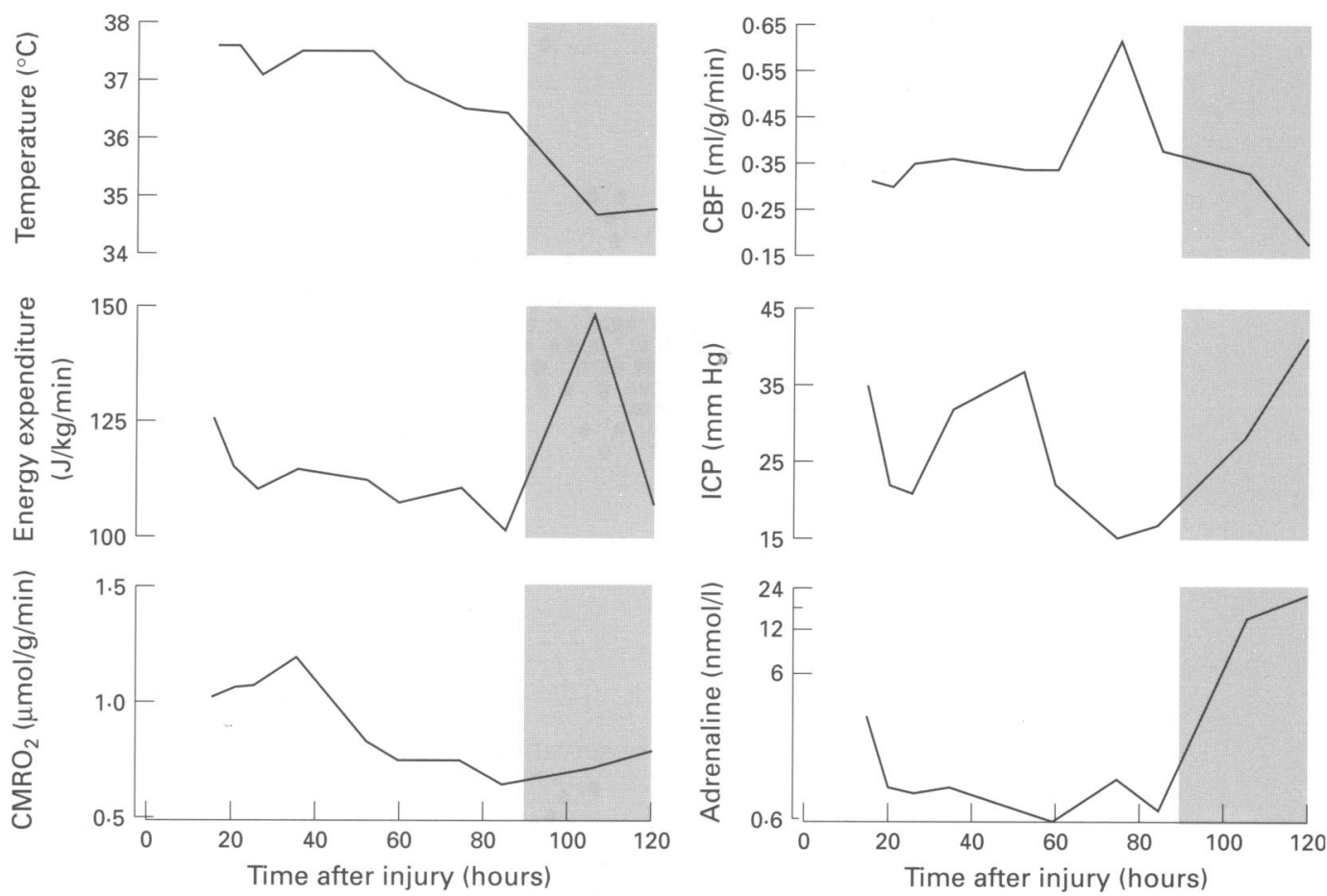

Figure 4 Shows rectal temperature, whole body energy expenditure, $C M R O, C B F, I C P$, and plasma adrenaline concentrations versus time after injury in one head injured child. Plasma adrenaline concentration is plotted on a log scale. The shaded area indicates the period of surface cooling to induce hypothermia.

reference range for $75(80 \%)$ measurements, raised for one $(1 \%)$ measurement, and depressed for $18(19 \%)$ measurements from six children. There is no suitable reference range available for ICP in normal children.

WITHIN CHILD RELATIONSHIPS BETWEEN WHOLE BODY ENERGY EXPENDITURE AND CORE TEMPERATURE

The within child relationship between log energy expenditure/kg body weight and rectal temperature in 18 children is shown in fig $3 \mathrm{~A}$. Using multilevel modelling a statistically significant positive relationship was found between log energy expenditure and rectal temperature $(p<0 \cdot 001)$. By taking the antilog of the slope of the regression line $(0.031)$, it was found that energy expenditure increases by a mean of $7 \cdot 4 \% /{ }^{\circ} \mathrm{C}$. Further details of the results of the statistical analysis are shown in table 2 .

Ambient temperature may influence the relationship between energy expenditure and core temperature. ${ }^{30}$ However, core temperature still had a significant positive relationship with $\log$ energy expenditure $(p<0.001$, regression slope 0.029 ) after allowing for the effects of ambient temperature in the multilevel model.

WITHIN CHILD RELATIONSHIP BETWEEN $\mathrm{CMRO}_{2}$ AND RECTAL TEMPERATURE

The within child relationship between log $\mathrm{CMRO}_{2}$ and rectal temperature in 15 children is shown in fig 3B. There was no evidence of a statistically significant relationship $(p=0.84$, regression slope $0 \cdot 004) . \mathrm{CMRO}_{2}$ increased by a mean of $1 \% /{ }^{\circ} \mathrm{C}$.
WITHIN CHILD RELATIONSHIP BETWEEN CBF AND RECTAL TEMPERATURE

The within child relationship between log CBF and rectal temperature in 15 children is shown in fig $3 \mathrm{C}$. There was no evidence of a statistically significant relationship $(p=0 \cdot 27)$. There are many other possible determinants of CBF which may be influenced by severe head injury. These include cerebral perfusion pressure, arterial oxygen content, and arterial partial pressure of carbon dioxide. ${ }^{31}$ In order to ascertain the effects of these variables on the relationship between $\mathrm{CBF}$ and core temperature, they were each included as covariates in a multilevel model with CBF. There was still no evidence for a statistically significant relationship between CBF and core temperature (temperature $p=0.64$, cerebral perfusion pressure $p=0 \cdot 21$, arterial oxygen content $p=0 \cdot 001$, arterial partial pressure of carbon dioxide $\mathrm{p}=0.002)$.

WITHIN CHILD RELATIONSHIP BETWEEN ICP AND RECTAL TEMPERATURE

The within child relationship between ICP and rectal temperature in 18 children is shown in fig 4 . No evidence of a statistically significant relationship was found $(p=0 \cdot 56)$.

EFFECT OF INDUCED MILD HYPOTHERMIA ON WHOLE BODY ENERGY EXPENDITURE, $\mathrm{CMRO}_{2}$, AND ICP

Two children were rendered mildly hypothermic (mean 34.0 , range $32 \cdot 6-34 \cdot 9^{\circ} \mathrm{C}$ ) as part of their management because of raised ICP resistant to treatment with hyperventilation and mannitol administration. One child was a girl of 10 years with a Glasgow coma 
score of 4 who had been involved in a road traffic accident. Despite neurointensive care, her ICP continued to increase and on day 5 surface cooling was started. Measurements of rectal temperature, whole body energy expenditure, $\mathrm{CMRO}_{2}, \mathrm{CBF}$, ICP, and plasma adrenaline concentrations were made when her temperature had stabilised. The serial measurements of these variables are shown in fig 4 . It can be seen that as the child's rectal temperature decreased, her whole body energy expenditure increased, the $\mathrm{CMRO}_{2}$ increased slightly, CBF decreased, ICP continued to increase and plasma adrenaline concentrations increased 10-fold. The child's condition continued to deteriorate and she died 24 hours after the final measurement.

The second child was a boy, aged 14 years, who had been involved in a cycling accident. Infusions of dopamine and noradrenaline were started simultaneously with surface cooling making the results of the observations difficult to interpret. However, a reduction of core temperature to $32 \cdot 6^{\circ} \mathrm{C}$ was not associated with a decrease in $\mathrm{CMRO}_{2}$ and ICP levels.

\section{Discussion}

After severe head injury, mean rectal temperature lay above the normal range and did not change significantly over time in this group of children. Body temperature is normally maintained in man within a limited range of $36 \cdot 5-37 \cdot 5^{\circ} \mathrm{C}$. The central thermoregulatory centre, located in the preoptic anterior hypothalamus, receives input from superficial and deep thermal receptors. ${ }^{32}$ Any discrepancy between central and peripheral temperatures and the central temperature 'setpoint' are detected and efferent reflexes generated to conserve or dissipate heat. Heat loss may be increased by peripheral vasodilation and sweating and decreased by vasoconstriction. ${ }^{33}$ Heat production may be increased by shivering $^{34}$ and non-shivering thermogenesis. ${ }^{35}$

Although body temperature is often reduced immediately after injury in adult man, body temperature and whole body metabolic rate increase after the first 24 hours. ${ }^{1}$ There is good evidence that this is secondary to an increase of the hypothalamic thermoregulatory setpoint. The increase of the thermoregulatory setpoint is believed to be mediated by interleukin-1 (IL1) produced by macrophages following tissue damage. ${ }^{36}$ Prostaglandins are thought to be the intermediaries in the actions of IL-1 and act by altering the activity of temperature sensitive neurones within the hypothalamus. ${ }^{37}$

Although there is evidence that the mechanisms for thermoregulation mature slowly in man, few studies have investigated thermoregulation after injury in children. High fevers are documented in children in the first 48 hours after thermal injury, a feature which is uncommon in burned adults. ${ }^{4}$ It was found that paracetamol reduced pyrexia in $80 \%$ of these children. The finding that paracetamol, a prostaglandin synthetase inhibitor, was an effective antipyretic agent suggests that the mechanism underlying the pyrexia in these burned children was an increase of the thermoregulatory setpoint. ${ }^{3}$ The head injured children in the present study showed a similar response to that described in burned children with raised temperatures occurring within nine hours of injury.

There was a highly significant positive relationship between log energy expenditure and rectal temperature in this group of severely head injured children. The mean increase in whole body energy expenditure was $7 \cdot 4 \% /{ }^{\circ} \mathrm{C}$. The Du Bois formula states that the mean increase in energy expenditure should be $13 \% /{ }^{\circ} \mathrm{C}$ in accordance with the van't Hoff law or $Q_{10}$ effect. ${ }^{5}$ However, deviations from the $\mathrm{Du}$ Bois formula have been found in studies of postoperative and injured adults ${ }^{38} 39$ and in burned children ${ }^{40}$ suggesting that surgery and trauma can effect changes in the rates of energy expenditure independent of temperature change. Raised metabolic rates increase nutritional demands, which being difficult to meet, result in tissue wasting and an increased susceptibility to infection. ${ }^{41}$ It seems reasonable, therefore, to reduce the raised core temperatures, if possible, with a centrally acting antipyretic such as paracetamol.

Mild hypothermia, induced by surface cooling and neuromuscular blockade, does not affect the thermoregulatory setpoint and so, as temperature falls, efferent output from the hypothalamus acts to attempt to restore normothermia. This is achieved by increased heat production, principally non-shivering thermogenesis mediated by large increases in catecholamine production. ${ }^{35} 42$ This response is shown in the first child treated with mild hypothermia described in the study where, contrary to expectations, there was an increase in whole body energy expenditure as body temperature decreased. The mild hypothermia may, therefore, have had potentially adverse consequences.

Many studies on animals and humans with intact uninjured brains show a significant positive relationship between $\mathrm{CMRO}_{2}$ and core temperature ${ }^{673}$ with temperature coefficients of $8 \cdot 4-15 \% /{ }^{\circ} \mathrm{C}$. It was surprising, therefore, to find no significant relationship between $\mathrm{CMRO}_{2}$ and core temperature. It is probable that $\mathrm{CMRO}_{2}$ is strongly influenced by factors induced by the response to trauma which are masking a relationship with core temperature. This conclusion is supported by the findings of a preliminary study of the effect of moderate therapeutic hypothermia after severe head injury in adult man. ${ }^{44}$ Mean $\mathrm{CMRO}_{2}$ decreased significantly during cooling but the temperature coefficient was low, about $2 \cdot 4 \% /{ }^{\circ} \mathrm{C}$, showing a marked deviation from the Du Bois formula.

In our study, core temperature was monitored using rectal temperature. If rectal temperature does not accurately reflect brain temperature after head injury, this could explain the poor relationship between $\mathrm{CMRO}_{2}$ and body temperature observed. However, aural temperature indirectly monitors the temperature of blood supplying the brain, and studies in normal adult humans comparing 
simultaneous measurements of rectal and aural temperatures have shown that aural temperature is usually within $\pm 0.5^{\circ} \mathrm{C}$ and that the pattern of change shows excellent correlation. ${ }^{4245}$ To the best of our knowledge, the relationship between rectal and aural temperature has not been studied after head injury.

There was no evidence of a significant relationship between either log CBF and body temperature or ICP and body temperature. Studies in the literature show that CBF has a positive relationship with temperature but the temperature coefficient is variable. ${ }^{67}$ This is because CBF is strongly influenced by factors which vary independently of temperature, for example, arterial oxygen content and arterial partial pressure of carbon dioxide, both of which were significantly related to $\mathrm{CBF}$ in our study. Studies in adult man after severe head injury have also shown a variable relationship between ICP and core temperature. ${ }^{44} 46$

In conclusion, most children became pyrexial after severe head injury and this is likely to be the result of an elevated thermoregulatory setpoint. As raised temperature was associated with raised whole body energy expenditure, it seems reasonable to treat the increased core temperatures with a centrally acting antipyretic such as paracetamol which may reduce the setpoint and, hence, body temperature. Whole body energy expenditure will thus decrease, reducing the nutritional demands on the head injured child. Conversely, although surface cooling may increase peripheral heat loss, it does not alter the central thermoregulatory setpoint and, thus, may have an adverse and unanticipated effect of increasing body metabolism.

There was no evidence of a significant positive relationship between raised or normal core temperature and $\mathrm{CMRO}_{2}, \mathrm{CBF}$, and ICP. Pyrexia is usually treated aggressively after severe head injury because of concerns that raised core temperatures will result in raised $\mathrm{CMRO}_{2}$, placing increased demands on a possibly compromised cerebral blood supply. However, it should not be assumed that the treatment of increased rectal temperatures will necessarily result in a reduction in $\mathrm{CMRO}_{2}$, which may be affected by many local stress induced factors.

The protective effect of hypothermia on cerebral function after severe head injury has not yet been fully elucidated. In our study, $\mathrm{CMRO}_{2}, \mathrm{CBF}$, and ICP did not decrease in two critically head injured children treated with mild hypothermia. However, there is evidence to suggest that the protective effect of hypothermia is unrelated to its effect on energy metabolism and may involve the stabilisation of cell membranes and the prevention of toxic levels of extracellular excitatory amino acids. ${ }^{478}$ Further studies are needed in order to fully evaluate this mode of management before it can be recommended for routine use.

We thank the medical and nursing staff of the intensive care unit, and the consultant neurosurgeons who allowed us to study their patients. We thank Dr P Sharples for her help with cerebral blood flow measurements. We are grateful to Dr A G bral blood flow measurements. We are grateful to Dr A G
Stuart, University Hospital of Wales, Cardiff, for his valuable Stuart, University Hospital of Wales, Cardiff, for his valuable
comments in preparing this manuscript and we acknowledge the assistance of $\mathrm{Mr} \mathbf{M}$ Ashby and Professor M Brown, Department of Clinical Pharmacology, Cambridge with adrenaline assays. Dr Matthews was supported by the Scientific and Research Committee of Newcastle Health Authority and by the Medical Research Council. We gratefully acknowledge additional financial support from the Intensive Care Society the Buttle Trust, the Mason Medical Foundation, the Pee Medical Research Trust, and CHILD.

1 Little RA. Heat production after injury. $\mathrm{Br}$ Med Bull 1985; 41: $226-31$

2 Stoner HB. Studies on the mechanism of shock. The impairment of thermoregulation by trauma. British fournal of Experimental Pathology 1969; 50: 125-38.

3 Childs C, Little RA. Acetaminophen (paracetamol) in the management of burned children with fever. Burns 1988 14: 343-8.

4 Childs C. Fever in burned children. Burns 1988; 14: 1-6. $\mathrm{Du}$ Bois EF. Basal metabolism in health and disease. Philadelphia: Lea and Febiger, 1936.

6 Michenfelder JD, Theye RA. Hypothermia: effect on canine brain and whole-body metabolism. Anaesthesiology 1968; 29: 1107-12.

7 Hagerdal M, Harp J, Nilsson L, Siesjo BK. The effect of induced hypothermia upon oxygen consumption in the rat induced hypothermia upon oxygen cons
brain. $₹$ Neurochem $1975 ; 24: 311-6$.

8 Elias-Jones AC, Punt JAG, Turnbull AE, Jaspan T. Management and outcome of severe head injuries in the Trent region 1985-90. Arch Dis Child 1992; 67: $1430-5$.

9 Matthews DSF, Aynsley-Green A, Matthews JNS, Bullock RE, Cooper BG, Eyre JA. The effect of severe head injury on whole body energy expenditure and its possible hormonal mediators in children. Pediatr Res 1995; 37 409-17.

10 Baker SP, O'Neill B, Haddon W, Long W. The injury severity score: a method for describing patients with multiple injuries and evaluating emergency care. $\mathcal{f}$ Trauma 1974 ; 14: $187-96$.

11 Teasdale G, Jennett B. Assessment of coma and impaired consciousness. Lancet 1974; ii: 81-4.

12 James HE, Trauner DA. The Glasgow coma scale. In: James HE, Anas NG, Perkin RM, eds. Brain insults in infants and HE, Anas NG, Perkin RM, eds. Brain insults in infants
children. London: Grune and Stratton, 1985: 179-82.

13 Chambers IR, Mendelow AD, Sinar EJ, Modar P. A clinical evaluation of the camino subdural screw and ventricular monitoring kits. Neurosurgery 1990; 26: 421-3.

14 Douglas CG. A method for determining the total respiratory exchange in man. Proceedings of the Physiological Society $1911 ; 17-8$

15 Fleck A, Munro HN. The determination of organic nitrogen in biological materials. A review. Clin Chim Acta 1965; 11: 2-12.

16 Westenskow DR, Cutler CA, Wallace WD. Instrumentation for monitoring gas exchange and metabolic rate in critically ill patients. Crit Care Med 1984; 12: 183-7.

17 Weir JB. New methods for calculating metabolic rate with special reference to protein metabolism. $\mathcal{F}$ Physiol (Lond) 1949; 109: $1-9$.

18 Brown MJ, Jenner DA. Novel double-isotope technique for enzymatic assay of catecholamines, permitting high precision, sensitivity and plasma sample capacity. Clin $\mathrm{Sc}$ 1981 ; 61: 591-8.

19 Kety SS, Schmidt CF. The nitrous oxide method for the quantitative determination of cerebral blood flow in man: theory, procedure and normal values. $\mathcal{F}$ Clin Invest 1948 27: 476-83.

20 Sharples PM, Stuart AG, Aynsley-Green A, et al. A practical method of serial bedside measurement of cerebral blood flow and metabolism during neurointensive care. Arch Dis Child 1991; 66: 1326-32.

21 Benumof $J L$. Respiratory physiology and respiratory function during anaesthesia. In: Miller RD, ed. Anaesthesia. New York: Churchill Livingstone, 1986: 1115-63.

22 Allott PR, Steward A, Flook V, Mapleson WW. Variation with temperature of the solubilities of inhaled anaesthetics in water, oil and biological media. Br f Anaesth 1973; 45: in water,

23 Ciba-Geigy. Geigy scientific tables. Basle: Ciba-Geigy, 1981 : 222

24 Astrup J, Sorensen PM, Sorensen HR. Inhibition of cerebral oxygen and glucose consumption in the dog by hypothermia, pentobarbital and lidocaine. Anaesthesiology 1981; 55: 263-8.

25 Goldstein $\mathrm{H}$. Multilevel models in education and social research. Oxford: Charles Griffin, 1987.

26 Prosser R, Rasbash J, Goldstein H. ML3: software for threelevel analysis. London: Institute of Education, 1991.

27 Raudenbush S. 'Centering' predictors in multilevel analysis choices and consequences. Multilevel Modelling Newsletter 1989; 1: 10-2.

28 Settergren G, Lindblad BS, Persson B. Cerebral blood flow and exchange of oxygen, glucose, ketone bodies, lactate, pyruvate and amino acids in anesthetized children. Acta Paediatr Scand 1980; 69: 457-65.

29 Schofield WN. Predicting basal metabolic rate, new standard and review of previous work. Human Nutrition: Clinical Nutrition 1985; 39C: 5-41.

30 Goldman RF. Effect of environment on metabolism. In: Kinney JM, ed. Assessment of energy metablism in health and disease. Columbus: Ross Laboratories, 1980: and diseas

31 Sharples PM, Matthews D, Crawford PJ, Mendelow AD, Chambers I, Eyre JA. Cerebral blood flow and
Chamber PM, Matthews D, Crawford PJ, Mendelow AD, 
metabolism in severely head injured children. Part 2: determinants of cerebrovascular resistance. If Neurol Neterminants of cerebrovascular resiatry 1995; 58: $153-9$.

32 Hardy JD, Hellon RF, Sutherland K. Temperature-sensitive neurones in the dog's hypothalamus. $\mathcal{F}$ Physiol (Lond) 1964; 175: 242-53.

33 Benzinger TH. On physical heat regulation and the sense of temperature in man. Proc Natl Acad Sci USA 1959; 45: 645-59.

34 Hemingway A. Shivering. Physiol Rev 1963; 43: 397-422.

35 Jessen K. An assessment of human regulatory nonshivering thermogenesis. Acta Anaesthesiol Scand 1980; 24: 138-43.

36 Atkins E. Fever - new perspectives on an old phenomenon. N Engl f Med 1983; 308: 958-60.

37 Stitt JT, Hardy JD, Stolwijk JA. PGE1 fever: its effect on thermoregulation at different low ambient temperatures. Am 7 Physiol 1974; 227: 622-9.

38 Kinney JM, Roe CF. Calorie equivalent of fever: 1. Patterns of postoperative response. Ann Surg 1962; 156: 610-22. 9 of postoperative response. Ann surg 1962, 156: $610-22$. Influence of major trauma. Ann Surg 1965; 161: 140-7.

40 Childs C, Little RA. Acute changes in oxygen consumption and body temperature after burn injury. Arch Dis Child 1994; 71: 31-5.

41 Dionigi R, Gnes F, Bonera A, Dominioni L. Nutrition and infection. Fournal of Parenteral and Enteral Nutrition 1979, 3: $62-8$.
42 Johnson DG, Hayward JS, Jacobs TP, Collis ML, Eckerson $\mathrm{JD}$, Williams RH. Plasma norepinephrine responses of man in cold water. $\mathcal{F} A$ ppl Physiol 1977; 43: 216-20.

43 Cohen PJ, Wollman H, Alexander SC, Chase PE, Behar MG. Cerebral carbohydrate metabolism in man during halothane anaesthesia. Effects of paCO2 on some aspects halothane anaesthesia. Effects of paCO2 on some aspects

44 Marion DW, Obrist WD, Carlier PM, Penrod LE, Darby JM. The use of moderate therapeutic hypothermia for patients with severe head injuries: a preliminary report. f Neurosurg 1993; 79: 354-62.

45 Cork RC, Vaughan RW, Humphrey LS. Precision and accuracy of intraoperative temperature monitoring. Anesth Analg 1983; 62: 211-4.

46 Clifton GL, Allen S, Barrodale P, et al. A phase II study of moderate hypothermia in severe brain injury. $f$ Neurotrauma 1993; 10: 263-71.

47 Hagerdal M, Harp J, Siesjo BK. Effect of hypothermia upon organic phosphates, glycolytic metabolites, citric acid cycle intermediates and associated amino acids in rate cycle intermediates and associated amino acids

48 Busto R, Dietrich WD, Globus MYT, Valdes I, Scheinberg temperature critically determine the extent of ischemic neuronal injury. F Cereb Blood Flow Metab 1987; 7: 729-38. 